\title{
PENGARUH KUALITAS LAPORAN KEUANGAN TERHADAP UMKM SERTA PROSPEK IMPLEMENTASI SAK ETAP
}

\author{
Kusuma Wijaya \\ Fakultas Ekonomi Universitas Islam Lamongan \\ Email : kusumawijaya785@gmail.com
}

\begin{abstract}
Abstrak
Penelitian ini untuk menguji pengaruh laporan keuangan UMKM terhadap tingkat kredit yang diterima UMKM, serta prospek dari implementasi SAK Entitas Tanpa Akuntabilitas Publik (SAK ETAP) di tahun 2011 terhadap peningkatan kualitas laporan keuangan UMKM.

Data dalam penelitian ini diperoleh dari kuesioner dengan responden pengusaha UMKM yang berada di wilayah Surabaya, Gresik, dan beberapa wilayah lain di pulau Jawa. Responden berjumlah 50 yang menjadi sampel dalam penelitian ini.

Hasil penelitian ini menunjukkan bahwa ternyata kualitas laporan keuangan UMKM tidakberpengaruh terhadap jumlah kredit yang diterima UMKM, hal ini dikarenakan masih rendahnya kualitas laporan keuangan UMKM sehingga perbankan masih meragukan relevansi dan keandalan kualitas laporan keuangannya. Prospek implementasi SAK ETAP terhadap peningkatan kualitas laporan keuangan sampai sejauh ini masih menghadapi kendala akibat masih rendahnya pemahaman para pengusaha UMKM atas SAK ETAP tersebut.
\end{abstract}

Kata kunci: Kualitas Laporan Keuangan, UMKM, Kredit, SAK ETAP

\section{PENDAHULUAN}

Semua perusahaan memiliki tujuan yang sama untuk mencapai keuntungan yang sebesarbesarnya. Untuk mencapai tujuan tersebut, maka setiap perusahaan akan mengarahkan kegiatan usahanya untuk menghasilkan produk yang dapat memberikan kepuasan kepada para konsumen, sehingga dalam jangka waktu yang cukup lama perusahaan mendapatkan keuntungan yang diharapkan. Akan tetapi, kenyataannya perusahaan tidak mudah mencapai target yang diinginkan. Usaha Mikro, Kecil, dan Menengah (UMKM) terbukti memberikan kontribusi bagi perekonomian Indonesia. UMKM mampu menyerap para pengangguran untuk dapat bekerja kembali. Di banyak negara, UKM juga memberikan kontribusi yang sama besarnya seperti yang terdapat di Indonesia. Afrika Selatan merupakan salah satu negara dengan 95\% sektor usahanya merupakan UMKM. Sektor ini setiap tahunnya rata-rata memberikan kontribusi sebesar 35\% terhadap produk domestik bruto, serta mampu mengurangi sebanyak 50\% tingkat pengangguran di Negara tersebut (Zimele 2009). Potensi yang besar dari UMKM tersebut sering terkendala 
masalah permodalan untuk mengembangkan usaha. Sebenarnya terdapat program pembiayaan UMKM yang dijalankan oleh pemerintah. Salah satu program tersebut adalah Kredit Usaha Rakyat (KUR) yang pada tahun 2009 ditargetkan sekitar Rp 20 triliun. Tujuan dari KUR tersebut adalah untuk menjadi solusi pembiayaan modal yang efektif bagi UMKM, sebab selama ini banyak UMKM yang terkendala akses terhadap perbankan untuk mendapatkan pembiayaaan (Osa 2010).

Namun realisasi KUR tersebut jauh dari target Rp 20 triliun yakni hanya sebesar Rp 14,8triliun. Penyebab rendahnya penyaluran KUR tersebut karena bank yang ditunjuk sebagai penyalur KUR sangat berhati-hati dalam penyaluran kredit, karena mereka tidak mendapatkan informasi yang memadai terkait kondisi UMKM. Mayoritas pengusaha UMKM tidak mampu memberikan informasi akuntansi terkait kondisi usahanya (Baas dan Schrooten2006).Dengan akuntansi yang memadai maka pengusaha UMKM dapat memenuhi persyaratan dalam pengajuan kredit, seperti pembuatan laporan keuangan (Warsono 2009). Laporan keuangan adalah suatu cerminan untuk dapat mengetahui apakah suatu kegiatan pemerintahan telah berjalan dengan baik, maka dari itu perbankan diharuskan untuk dapat menghasilkan laporan keuangan yang berkualitas, sehingga dari publikasi laporan keuangan tersebut dapat berguna bagi pihak yang berkepentingan dan menjadi dasar pengambilan keputusan(Wijaya, 2018).

Namun pelaksanaan pembukuan tersebut merupakan hal yang sulit bagi UMKM karena keterbatasan pengetahuan mengenai akuntansi,rumitnya proses akuntansi, dan anggapanbahwa laporan keuangan bukanlah hal yang penting bagi UMKM (Said 2009). Berbagai macam keterbatasan lain yang dihadapi UMKM adalah latar belakang pendidikan yang tidak paham akuntansi atau tata buku, kurang disiplin dalam melaksanakan pembukuan akuntansi, serta tidak adanya dana yang cukup untuk mempekerjakan akuntan atau membeli software akuntansi untuk mempermudah pelaksanaan pembukuan akuntansi.

Dewan Standar Akuntansi Keuangan( DSAK) pada tahun 2009 telah mensahkan Standar Akuntansi untuk Entitas Tanpa Akuntabilitas Publik (SAK ETAP). SAKETAP tersebut akan berlaku efektif per 1 Januari 2011 namun penerapan sebelum tanggal efektif diperbolehkan. Penggunaan SAK ETAP ini adalah ditujukan untuk entitas tanpa akuntabilitas publik yakni entitas yang : 
1. Tidak memiliki akuntabilitas publik yang signifikan,

2. Entitas yang menerbitkan laporan keuangan untuk tujuan umum bagi pengguna eksternal.

SAK ETAP merupakan standar akuntansi yang penggunaannya ditujukan untuk entitas usaha yang tidak memiliki akuntabilitas publik, seperti entitas usaha mikro, kecil, dan menengah (UMKM).SAK ETAP ini lebih mudah dipahami dan tidak sekompleks SAK Umum. Selain adanya SAK ETAP tersebut, kemudahan lain bagi UMKM dalam hal pembukuan akuntansi adalah semakin banyaknya software akuntansi yang dapat digunakan UMKM. Ke depannya diharapkan UMKM mampu melakukan pembukuan akuntansi untuk menyajikan laporan keuangan sehingga lebih mudah bagipara pengusaha UMKM untuk memperoleh pembiayaan.

1. Berdasarkan hal tersebut, maka menarik untuk dilakukan penelitian mengenai factor factor yang mempengaruhi persepsi pengusaha UMKM terkait pentingnya pembukuan dan pelaporan keuangan bagi usahanya kualitas laporan keuangan UMKM

2. apakah kualitas laporan tersebut berpengaruh pada besaran kredit yang disetujui oleh bank, dan 3) menilai prospek penerapan SAK ETAP di tahun 2011 yang didasarkan pada pemahaman yang dimiliki oleh pengusaha UMKM terkait SAK ETAP tersebut.

\section{KERANGKA TEORITIS}

Kebanyakan dari UMKM hanya mencatat jumlah uang yang diterima dan dikeluarkan, jumlah barang yang dibeli dan dijual, dan jumlah piutang/utang.Namun pembukuan tersebut tidak dengan format yang diinginkan oleh pihak perbankan. Mempekerjakan seseorang secara khusus untuk melakukan pembukuan akuntansi dan penyusunan laporan keuangan masih menjadi hal yang kurang realistis bagi banyak UMKM sebab akan menambah pengeluaran untuk membayar gaji tenaga akuntansi tersebut. Murniati (2002) meneliti mengenai factor-faktor yang mempengaruhi penyiapan dan penggunaan informasi akuntansi pada perusahaan kecil di Jawa Timur dengan sampel sebanyak 283 pengusaha kecil dan menengah .Ditemukan bahwa karakteristik pemilik/manajer (masa memimpin, Pendidikan formal manajer/pemilik, dan pelatihan akuntansi yang diikuti manajer/pemilik) serta karakteristik perusahaan kecil dan menengah (umur perusahaan, sektor industri, dan skala usaha) secara signifikan berpengaruh positif terhadap penyiapan dan penggunaan informasi akuntansi pada perusahaan. Penelitian 
Pinasti (2001) menemukan bahwa para pedagang kecil di pasar tradisional di kabupaten Banyumas tidak menyelenggarakan dan tidak menggunakan informasi akuntansi dalam pengelolaan usahanya.

Keputusan-keputusan dalam pengelolaan usaha lebih banyak didasarkan pada informasiinformasi non akuntansi dan pengamatan sepintas atas situasi pasar. Secara umum mereka menganggap informasi akuntansi tidak penting. Alasan-alasan yang dikemukakan antara lain:mereka merasa terlalu direpotkan dengan penyelenggaraan catatan akuntansi tersebutd an yang penting mereka mendapatkan laba tanpa dibebani dengan penyelenggaraan akuntansi. Mereka belum merasakan manfaat dari penyelenggaraan pembukuan.

Baas dan Schrooten berkesimpulan bahwa hampir di seluruh dunia UMKM mengalami kesulitan dalam mendapatkan kredit perbankan. Salah satu penyebabnya adalah adanya keterbatasan informasi yang mampu diberikan oleh UMKM kepada pihak eksternal. Saran yang diberikan dalam penelitian tersebut adalah pentingnya standar akuntansi yang mampu mengakomodir kebutuhan dari pengusaha UMKM, agar dapat membantu UMKM dalam menyediakan informasi keuangan yang lebih berkualitas. Cziráky et al. (2005) meneliti mengenai faktor-faktor yang menyebabkan rendahnya pemberian kredit UMKM di Kroasia.

Program kredit UMKM yang dijalankan pemerintah Kroasia ternyata penyaluran kreditnya rendah, padahal pemerintah telah memberikan subsidi terhadap tingkat suku bunganya serta pasokan dana yang dianggap mencukupi kebutuhan kredit bagi UMKM. Hasil penelitian mereka menunjukkan bahwa rata-rata perbankan tidak konsisten dalam hal penggunaan criteria persetujuan kredit. Ketidak konsistenan tersebut dikarenakan adanya perbedaan keahlian dan pengetahuan dalam penilaian kredit dari para pegawai bank di negara tersebut. Terdapat preferensi dari pihak perbankan untuk lebih menyetujui pemberian kredit dengan jumlah kecil dan untuk perusahaan kecil yang tergolong lebih aman. Kondisi tersebut terjadi akibat perbankan tergolong risk averseyang disebabkan kurangnya informasi dalam proses penilaian kredit. Bornheim dan Herbeck (1996) menyebutkan faktor-faktor yang mampu mempengaruhi hubungan antara bank dan pengusaha UMKM, antara lain: dari sisi perbankan yang berupaketersediaan informasi debitur, persaingan antar perbankan, dan biaya promosi produk, sedangkan dari sisi pengusaha UMKM faktor yang mempengaruhi hubungan dengan perbankan dapat berupa besarnya jaminan, akses terhadap kredit, dan cost of capital atas pilihan untuk 
melakukan pinjaman yang terlihat dari besarnya bunga pinjaman yang berlaku. Jati et al. (2004) menyatakan bahwa pada saat ini kebanyakan UMKM masih belum menyelenggarakan pembukuan akuntansi dan pelaporannya dengan baik. Pelaksanaan pembukuan akuntansi untuk menyediakan laporan keuangan yang informatif merupakan hal yang masih sulit bagi UMKM. Hal ini disebabkan karena keterbatasan pengetahuan dalam pembukuan akuntansi, rumitnya proses akuntansi, dan anggapan bahwa laporan keuangan bukanlah hal yang penting bagi UMKM (Said 2009). Maseko dan Manyani (2011) juga menemukan bahwa mayoritas UKM di Zimbabwe tidak mempunyai pencatatan akuntansi yang lengkap karena keterbatasan pengetahuan akuntansi.

Persepsi merupakan suatu proses dari individu dalam memilih, mengelola, dan menginterpretasikan suatu rangsangan yang diterimanya ke dalam suatu penilaian terkait apa yang ada di sekitarnya (Schiffman dan Kanuk 2010). Persepsi menjadi titik awal seseorang dalam menilai dan menjalankan suatu hal, termasuk pembukuan dan pelaporan keuangan. Dengan memandang bahwa pembukuan dan pelaporan merupakan hal yang penting bagi berkembangnnya usaha, maka akan mendorong mereka untuk memulai melakukan pembukuan atau bagi yang sudah memulai dapat lebih lagi meningkatkan kualitas laporan keuangannya. Terdapat beberapa hal yang diduga dapat mempengaruhi persepsi pengusaha terkait pentingnya pembukuan dan pelaporan keuangan bagi tumbuh dan berkembangnya usaha seperti jenjang pendidikan terakhir, latar belakang pendidikan, ukuran usaha, serta lama usaha berdiri. Jenjang pendidikan yang lebih tinggi akan meningkatkan kemampuan menyerap (termasuk kemampuan akuisisi, asimilasi, transformasi, dan eksploitasi) dari pengetahuan baru (Gray 2006; Van Hermert et al. 2011). Murniati (2002) menemukan bahwa pengusaha dengan jenjang pendidikan formal yang rendah cenderung tidak memiliki persiapan dan penggunaan informasi akuntansi yang memadai dibandingkan pengusaha yang memiliki pendidikan formal lebih tinggi.Hal tersebut dikarenakan materi akuntansi didapatkan pada jenjang pendidikan yang lebih tinggi.Selain itu, latar belakang pengusaha UMKM dapat mempengaruhi persepsinya terkait pentingnya pembukuan dan pelaporan keuangan bagi tumbuh dan berkembangnyausaha.

Pengetahuan mengenai akuntansi dan kegunaan dari laporan keuangan terutama didapatkan apabila seseorang menempuh pendidikan dengan jurusan akuntansi. Pengusaha dengan latar belakang akuntansi diyakini akan mempunyai persepsi yang lebih baik mengenai 
SAK ETAP dibandingkan pengusaha dengan latar belakang pendidikan non akuntansi. Pinasti (2001) menemukan bahwa ukuran usaha merupakan faktor yang sulit dipisahkan dengan lingkungan pengusaha UMKM.Ukuran usaha dapat mempengaruhi pemikiran pengusaha terkait dengan kompleksitas dan semakin tingginya tingkat transaksi perusahaan sehingga diharapkan dengan makin besarnya ukuran usaha dapat mendorong sesorang untuk berpikir dan belajar terkait solusi untuk menghadapinya.Ukuran usaha yang besar berimplikasi perusahaan mempunyai sumber daya yang lebih besar dan juga lebih mampu mempekerjakan karyawan dengan keahlian yang lebih baik (Gray 2006). Ukuran usaha diduga akan berpengaruh positif terhadap persepsi UMKM. Lama suatu usaha berdiri diduga memberikan pengaruh positif terhadap persepsi pengusaha UMKM mengenai SAK ETAP. Menurut Amburgey et al. (1993) dan Henderson (1999), dalam Anderson dan Eshima (2011), umur usaha yang semakin panjang memberikan keuntungan dalam hal telah mempunyai struktur dan proses yang rutin yang mendisiplinkan setiap tindakan perusahaan. Termasuk dalam proses tersebut adalah proses pembukuan. Das dan Dey (2005) menemukan adanya hubungan positif antara umur usaha UMKM dengan frekuensi melakukan pembukuan secara teratur. UMKM dengan umur yang lebih panjang yang melakukan pembukuan dengan lebih teratur, diduga akan mempunyai persepsi yang lebih baik mengenai SAK ETAP.

Kondisi ekspansi kredit untuk UMKM pada triwulan pertama tahun 2010 yang telah mencapai Rp. 45,5 triliun atau meningkat sangat pesat dari triwulan pertama tahun 2009 yang hanya mencapai Rp. 3,4 triliun (meningkat sekitar 1.238,2\%). Hal tersebut mengindikasikan tingginya penyaluran kredit perbankan terhadap UMKM. Berdasarkan Baas dan Schrooten (2006) bahwa salah satu teknik pemberian kredit yang paling banyak digunakan adalah financial statement lending yang mendasarkan pemberian kreditnya atas informasi keuangan dari debiturnya. Namun di sisi lain hal tersebut menjadi kendala tersendiri sebab UMKM ternyata tidak mampu menyediakan informasi yang diperlukan oleh bank tersebut. Cziráky et al. (2005) menyatakan bahwa penyebab rendahnya tingkat penyaluran kredit UMKM adalah perbankan tidak memiliki cukup informasi dalam melakukan penilaian kelayakan kredit. Kedua penelitian kredit. Selain kualitas laporan keuangan, terdapat beberapa faktor lain yang menurut penelitian terdahulu mempengaruhi besaran kredit yang diterima UKM. Ukuran perusahaan merupakan salah satu faktor penting dalam mendapatkan akses pendanaan (Audretsch dan Elston1997). 
Perusahaan yang lebih kecil dianggap mempunyai risiko yang lebih besar mengalami kesulitan keuangan (Mac an Bhaird dan Lucey2010). Semakin besar ukuran perusahaan akan semakin mudah untuk mendapatkan pendanaan dari perbankan.

Selain ukuran usaha, umur perusahaan juga menjadi salah satu faktor yang mempengaruhi UKM untuk memperoleh kredit dari perbankan. Semakin matang suatu perusahaan akan lebih mudah untuk memperoleh kredit,karena perusahaan yang lebih muda lebih besar kemungkinannya mengalami kegagalan usaha dibandingkan perusahaan dengan umur usaha yang lebih panjang (Cressy2006). Mac and Bhaird dan Lucey (2010) menyatakan bahwa perusahaan yang baru berdiri seringkali mengalami kesulitan untuk mendapatkan pendanaan dari bank karena adanya permasalahan asimetri informasi dan kemungkinan masalah keagenan yang timbul terkait belum pernahnya bank memberikan kredit ke perusahaan tersebut. UKM seringkali mempunyai keterbatasan aset untuk dijadikan jaminan kredit. Padahal salah satu informasi yang digunakan perbankan dalam keputusan menyalurkan kredit adalah menggunakan informasi terkait aset-aset yang dijadikan jaminan (Assets Based Lending) (Baas dan Schrooten 2006). UKM yang memiliki aset untuk dijadikan jaminan kredit,akan lebih besar kemungkinannya untuk mendapatkan kredit dari perbankan. Kirschenmann dan Norden (2010) melakukan penelitian mengenai hubungan antara risiko debitur dan jangka waktu kredit untuk kredit yang diberikan perbankan keusaha kecil. Mereka menemukan adanya hubungan positif, yang artinya semakin besar jangka waktu kredit maka akan meningkatkan risiko pinjaman. Oleh karena itu diduga jangka waktu (termin kredit) akan berpengaruh negatif terhadap jumlah kredit yang diberikan perbankan ke pengusaha UMKM.

SAK ETAP bertujuan untuk dapat mengakomodir kebutuhan entitas yang tidak memiliki akuntabilitas publik signifikan. Selain itu juga untuk membantu membuat standar akuntansi yang dapat digunakan oleh UMKM karena sifatnya yang lebih ringkas dan mudah digunakan dibandingkan dengan SAK Umum.Hal terpenting dari implementasi SAK ETAPadalah pemahaman yang baik atas SAK ETA Ptersebut oleh UMKM tersebut.Pemahaman terkait SAK ETAP tersebuterat kaitannya dengan proses pemberian informasi dan sosialisasi. Apabila pengusaha mendapatkan informasi dan sosialisasi dengan baik, maka pemahaman mereka terkait SAK ETAP akan menjadi lebih baik dan mendukung proses implementasi SAK ETAP di tahun2011. Selain proses pemberian informasi dan sosialisasi terkait SAK ETAP, diduga juga 
terdapat pengaruh dari jenjang pendidikan terakhir serta latar belakang pendidikan dari pengusaha UMKM terhadap pemahaman atas SAK ETAP. Sebagaimana dijelaskan di bagiansebelumnya, jenjang pendidikan yang lebih tinggi mampu meningkatkan kemampuan seseorang untuk menyerap pengetahuan baru .Gray (2006) menyatakan bahwa kemampuan menyerap pengetahuan dipengarui juga oleh ukuran usaha. Ukuran usaha yang besar mengindikasikan perusahaan mempunyai sumber daya yang lebih banyak, termasuk karyawan dengan keahlian yang lebih baik, sehingga UMKM dengan ukuran yang lebih besar diharapkan mempunyai pemahaman yang lebih baik mengenai SAK ETAP.

Penelitian sebelumnya menemukan adanya hubungan positif antara umur usaha UMKM dengan frekuensi melakukan pembukuan secara teratur (Das dan Dey 2005). Pembukuan yang teratur mengindikasikan UMKM memahami mengenai kegunaan pembukuan dan juga kebutuhan atas standar akuntansi untuk melakukan pembukuan tersebut. Oleh karena itu, diduga UMKM dengan umur yang lebih panjang akan mempunyai pemahaman yang lebih baik mengenai SAK ETAP.

\section{METODE PENELITIAN}

Data yang digunakan berasal dari kuesioner yang dibagikan kepada 30 pengusaha UMKM yang terdapat di wilayah sekitar Gresik dan Surabaya, dengan cara mendatangi langsung sehingga semua kuesioner dapat terisi. 30 responden yang dipilih tersebut adalah responden yang berdasarkan pengamatan mempunyai skala usaha yang belum terlalu besar. Di dalam kuesioner juga terdapat pertanyaan mengenai jumlah pegawai, total aset, dan total penjualan untuk menentukan apakah responden tersebut memang merupakan UMKM. Berdasarkan jawaban yang diberikanke 30 responden tersebut, semuanya merupakan UMKM. Selain itu juga dilakukan pengiriman kuesioner melalui email kepada pengusaha yang berada di kota-kota lain di pulau Jawa, sejumlah 90 dengan jumlah kuesioner yang kembali 20 buah. Total jumlah responden keseluruhan adalah 50 responden (rata-rata tingkat pengembalian adalah 41,67\%), yaitu pengusaha UMKM yang ukuran usahanya tidak tergolong usaha besar, dan berlokasi di wilayah Gresik, Surabaya, dan kota-kotalain di pulau Jawa. Selain menggunakan data dari kuesioner, penelitian ini ditunjang dengan proses wawancara dengan UKM Centre FEUI selaku pihak yang menjembatani antara pengusaha UMKM dengan perbankan serta pihak yang turut serta 
membantu memberikan pelatihan teknis terkait pengembangan usaha UMKM dan responden yang merupakan pengusaha UMKM.

\section{ANALISIS HASIL DAN PEMBAHASAN}

Sebaran sampel berdasarkan lokasi usahanya adalah sebanyak 42 responden berada di wilayah Surabaya dan 8 reponden berada di Gresik. Pendidikan formal terakhir yang ditempuh oleh para responden didominasi lulusan SMA/SMK yakni sebanyak 34 responden. Berdasarkan jenis usaha yang dijalankan, mayoritas responden bergerak dalam bidang perdagangan atau jual beli yakni sebanyak 34 responden, kemudian delapan responden usahanya bergerak di bidang jasa, enam responden di bidang manufaktur, dan dua responden di bidang agrobisnis (pertanian). Jika dikelompokkan berdasarkan ukuran usahanya, 24 responden memiliki usaha yang tergolong sebagai kelompok usaha mikro, 16 responden masuk ke dalam kelompok usaha kecil, dan 10 responden tergolong kelompok usaha menengah. Untuk responden yang pernah mendapatkan kredit perbankan adalah sebanyak 33 responden.

Persepsi pentingnya pembukuan dan pelaporan keuangan tersebut kemungkinan muncul dari semakin besarnya kebutuhan untuk memiliki suatu laporan keuangan untuk berbagai tujuan seperti persyaratan pengajuan kredit, evaluasi usaha, dan sebagai input untuk keputusan melakukan ekspansi usaha. Banyak dari pengusaha UMKM mulai memperhatikan proses pembukuan dan pelaporan keuangan untuk dapat mengatasi permasalahan manajemen keuangan serta kredit tersebut. Namun dilihat dari variabel kualitas laporan keuangan terlihat kualitas laporan keuangan memiliki kisaran yang cukup lebar dan nilai standar deviasi yang cukup tinggi, yang menunjukkan kualitas laporan keuangan yang dihasilkan responden cukup bervariasi. Lebih lanjut, berdasarkan variable pemahaman SAK ETAP terlihat bahwa 90\% dari responden belum mengetahui dan belum paham mengenai SAKETAP. Kemungkinan penyebabnya adalah karena tingkat informasi dan sosialisasi SAK ETAP yang diterima mereka masih relative terbatas .64\% responden mengaku belum pernah menerima sosialisasi dan informasi yang memadai terkait SAK ETAP.

Berdasarkan jenjang pendidikan terakhir, mayoritas responden berpendidikan SMA/SMK yang dapat menyebabkan terbatasnya pengetahuan mereka mengenai perkembangan terakhir yang mempengaruhi bisnis mereka, termasuk perkembangan standar akuntansi. $48 \%$ skala usaha 
responden adalah skala mikro, 32\% skala kecil, dan 30\% merupakan UKM dengan skalamenengah. manajemen, sehingga kemungkinan mereka kurang paham atas pentingnya akuntansi dan pelaporan keuangan. 34\% dari responden tidak mempunyai kredit dari perbankan. Sekitar 50\% mempunyai kredit dari bank dengan jumlah yang relative kecil, yaitu maksimal hanya sebesar Rp25 juta, dan mayoritas juga mempunyai nilai. Pada saat usaha baru berdiri akan mendorong seorang pengusaha untuk lebih giat mencari informasi dan cara untuk dapat mengembangkan usahanya dimasa yang akan datang. Menurut Mazanai dan Fatoki (2012), perusahaan yang baru berdiri mempunyai potensi pendanaan internal yang terbatas sehingga lebih memerlukan sumber pendanaan eksternal. Untuk mendapatkan kredit dari perbankan, mereka perlu menyiapkan laporan keuangan sehingga perlu mempunyai pemahaman yang memadai atas standar akuntansi.

Berdasarkan hasil tersebut di atas, maka dapat dikatakan prospek implementasi SAKETAP di tahun 2011 untuk meningkatkan kualitas laporan keuangan UMKM belum optimal. Mengingat hingga saat ini pemahaman mengenai SAK ETAP yang dimiliki pengusaha UMKM masih sangat rendah. Dari hasil wawancara juga diketahui bahwa Pembina UMKM pun masih memiliki pemahaman yang kurang mengenai SAK ETAP tersebut. Saat ini lembaga pembinaan UKM masih berfokus pada pelatihan teknik dasar akuntansinya daripada pedoman standar akuntansinya.

\section{KESIMPULAN}

Respoden UMKM dalam penelitian ini memiliki persepsi bahwa pembukuan dan pelaporan keuangan merupakan hal yang cukup penting dalam pertumbuhan dan perkembangan usahanya. Faktor ukuran usaha berpengaruh positif terhadap persepsi tersebut. Lama usaha berdiri justru berpengaruh negative terhadap persepsi, berbeda dengan dugaan awal. Mungkin karena pada saat awal berdiri pengusaha berusaha memikirkan hal-hal yang penting dilakukan untuk meningkatkan usahanya ke depan sehingga mereka lebih mempunyai persepsi yang baik akan pentingnya pembukuan dan pelaporan keuangan. Sedangkan jenjang pendidikan terakhir besertalatar belakang pendidikannya tidak terbukti signifikan Kualitas laporan keuangan UMKM di Indonesia saat ini masih tergolong rendah, rendahnya kualitas laporan keuangan UMKM 
menyebabkan kualitas laporan keuangan tidak berpengaruh positif terhadap besarnya jumlah kredit yang diterimanya.

SAK ETAP menjadi harapan untuk dapat meningkatkan kualitas laporan keuangan UMKM menjadi lebih baik dari yang ada saat ini. Implementasinya di tahun 2011 nampaknya masih menemui kendala yang dikhawatirkan menghambat penerapan SAK ini. Kendala terbesar adalah masih rendahnya pemahaman para pengusaha UMKM yang kelak akan menggunakan SAK ini. Pemberian informasi dan sosialisasi serta jenjang Pendidikan terakhir pengusaha ternyata berpengaruh positif terhadap tingkat pemahaman pengusaha terkait SAK ETAP ini. Sedangkan lama usaha berdiri berpengaruh negatif pada tingkat pemahaman pengusaha serta latar belakang pendidikan dan ukuran usaha tidak mempunyai pengaruh terhadap pemahaman pengusaha terkait SAK ETAP. Selain itu, pihak perbankan atau lembaga UMKM saat ini pun masih banyak yang belum sepenuhnya memahami mengenai SAK ETAP. Kondisi tersebut perlu menjadi perhatian pihak-pihak terkait (seperti IAI, Kementerian KUKM) bahwa selama ini pemberian informasi dan sosialisasi masih belum efektif dan mencapai target yang diinginkan.

Keterbatasan dalam penelitian ini adalah masih rendahnya pemahaman responden mengenai pentingnya pembukuan bagi perkembangan usahanya menyebabkan terbatasnya kemampuan model penelitian untuk menjawab hipotesis. Keterbatasan lainnya adalah jumlah responden yang masih terbatas dan sebagian besar berlokasi di Surabaya dan sekitarnya. Responden yang dijadikan sampel penelitian terdiri dari perusahaan dengan skala menengah, kecil, dan mikro, yang memilikik arakteristik yang berbeda. Kelompok mikro mungkin membutuhkan standar akuntansi yang jauh lebih sederhana dibandingkan SAK ETAP.

\section{DAFTAR PUSAKA}

Wijaya, K. (2018). Jurnal Penelitian Ilmu Manajemen 795. Jurnal Penelitian Ilmu Manajemen, III(3), 795-807.

Ibeng, Parta. 2018. UMKM: Pengertian,Ciri,Kriteria dan Jenis. Diambil dari :https://pendidikan.co.id/umkm-pengertian-ciri-kriteria-jenis-kelebihan/\#!

Budiutomo, Setya. 2017. Pengaruh Akuntansi Berbasis Etap Terhadap

Kualitas Laporan Keuangan UMKM. Diambil dari :

http://ejuoernal.upi.edu/index.php/JRAK/article/view/9217 
P-ISSN : 2477-6092

E-ISSN : 2620-3391

http://ojs.stie-labuhanbatu.ac.id/index.php/

Reza.2013 Pengertian, Karakteristik, dan Faktor-faktor UKM. Diambil dari https://mahrezarerezqy2013.wordpress.com/wp-admin/opinions-general .php
JURNAL ECOBISMA Vol.6 No.2 2019 